\title{
Citation:
}

Beal, C.D., Gurung, R.T., Stewart, R.A. (In press) Modelling the impacts of water efficient technologies on energy intensive water systems in remote and isolated communities. Clean Technologies and Environmental Policy, DOI: 10.1007/s10098-016-1241-9

http://link.springer.com/article/10.1007/s10098-016-1241-9

\section{Modelling the impacts of water efficient technologies on energy intensive water systems in remote and isolated communities}

C. Beal*

Smart Water Research Centre, and School of Engineering, Griffith University, Qld, Australia e-mail: c.beal@griffith.edu.au

Thulo Ram Gurung

School of Engineering, Griffith University, Qld, Australia

e-mail: r.gurung@griffith.edu.au

\section{R.A. Stewart}

School of Engineering, Griffith University, Qld, Australia

e-mail: r.stewart@griffith.edu.au

* Corresponding author 


\begin{abstract}
Essential service providers face unique challenges that are specific delivering a secure and safe water and energy supply to remote communities such as islands and isolated mainland townships. Many remote communities rely on energy intensive water supply systems which are inherently costly to operate. Water demand management programs such as retrofitting households with water-efficient devices and appliances are one way of reducing the water-energy costs in these communities. This paper presents modelling results from a comparison between business as usual and a scenario where water efficient strategies were retrofitted in households in three remote communities in Northern Australia. The modelling demonstrated considerable savings to both the water and energy average daily consumption and associated economic costs though reduced reliance on desalination plants and bore pumping. The retrofit scenario was shown to reduce water demand by between 14 and $39 \mathrm{ML} / \mathrm{y}$ and total energy demand in off-grid communities by between 83 and $208 \mathrm{MWh} / \mathrm{y}$. Cost reductions for delivering treated water to households ranged between around AUD\$11,000 and AUD\$70,000 per year, depending on uptake rates of the retrofit program by each community. This paper forms part of Stage 1 of the Remote and Isolated Communities Essential Services (RICES) project. Stage 2 will confirm many of the assumptions underlying the modelling and build on the smart metering datasets and community engagement process currently underway in Stage 1. The overall outcome of the RICES project is to ensure that such strategies are practical to implement on a broader scale to ultimately achieve more sustainable water and energy efficient off-grid communities.
\end{abstract}

\title{
Keywords
}

Water-energy nexus, off-grid, energy efficiency, demand management, island communities, Indigenous communities

\section{Introduction}

In Australia, there is typically a high percentage of Aboriginal and/or Torres Strait Island people living and working in regional, isolated and remote communities both on the mainland and coastal islands. Often these isolated Indigenous communities are not well serviced and suffer from poor health, social disunity and a lack of accessible education and health services (Moran and Corpus, 2013) In some cases, the social and economic conditions of such communities can reflect those of developing countries where access to reliable health, education, water and energy services are tenuous at best. Adequate, safe and reliable supply of water and energy is intimately linked to Indigenous health and social well-being, be it in Australia (Burgess et al. 2013; Hunter 2007) or elsewhere (Mohtar and Lawford, 2016; Kaygusuz 2011). Water supply choice in regional and remote communities is often limited and seasonally unreliable, impacting on delivery infrastructure, the function of household stock, and the health and well-being of residents Beard et al. (2011). Despite this, many Australian Indigenous communities have very high (> 700 litres) per capita water consumption (Beard et al. 2011, Hoverman and Ayre 2012) and often require energy intensive water supply systems for providing reliable potable water (Grey-Gardner 2008, Willis et al 2008). For example, most Torres Strait Islanders rely solely on energy intensive desalinated water, powered by diesel generators, to supply their community needs, resulting in 
significant economic and environmental impacts (Richards and Schäfer 2003, Werner and Schäfer 2007) The need for improved management of essential services (water and energy) in Indigenous communities is well acknowledged (Hoverman and Ayre 2012, Fisher et al. 2011, and gaining a good understanding of the typical baseline energy and water flows within such communities is a critical first step (Beal et al 2014). Essentially: knowing the "how, when and where" of the water and water relatedenergy within these communities is the fundamental starting point from which all subsequent planning and management initiatives can begin.

\section{Challenges in managing essential services in isolated communities}

There are a multitude of unique challenges that relate to remote and isolated Aboriginal and Torres Strait Island communities and their service providers in northern Australia. Community-based challenges include: geographic isolation and distance to larger townships; increased isolation during the wet season; variable reliability of energy supplies; infrequent maintenance support for supply infrastructure due to challenging remote locations; and the high and ever-increasing cost of energy supply (Hoverman and Ayre 2012). Underlying all these practical challenges are the cultural and social complexities inherent in Indigenous communities which need to be fully integrated into any long-term strategies in addressing essential service management (Yuen 2004).

Challenges for the essential services provider include: increased demand of energy and water-related energy; balancing the increased demand with supply, delivery and maintenance costs; uncertainty in planning future infrastructure due to a lack of baseline consumption data (across seasons and populations); energy generation and water treatment systems with variable capacity and changing demand patterns (transient population); variable reliability of on-site services (e.g. diesel pump for energy supply, water pump); and variable skill base for maintenance and repairs.

One of the biggest challenges for supplying water and energy to remote and isolated communities is that the necessary subsidies for covering the shortfall between the cost and revenue for providing these services sometimes means there is less focus on efficiency and higher rates of consumption than in urban areas. For example, approximately 75,000 L/annum of diesel is estimated to power the desalination plants on one Torres Strait Island to provide potable water to the community. The cost to supply barged water is $\$ 14$ per kilolitre (about 26 times the national average) and desalinated water is about $\$ 7$ per kilolitre (about 10 times national average). This diesel is needed to be shipped by transporter from mainland Australia - adding further environmental and financial costs to the water supply chain. Demand management education and retrofit programs underpinned by empirical data and suitably adapted for Indigenous communities, could help reduce the shortfall between cost and revenue, while also improving the long-term sustainability of water and energy supply. While modern alternative supply technologies (e.g. renewable energy systems with storage for energy supply; wind-DG-battery forward osmosis for water) can significantly reduce the resource intensity of supply (Werner and 
Schäfer 2007, Shezan et al. 2015), demand management activities such as education and appliance retrofit programs could also help to reduce demand and put the community on a more sustainable path to long-term water and energy supply. This is particularly pertinent in areas where these modern alternative supplies mentioned above are constrained by various climatic, economic, social and environmental challenges that are inherent isolated and remote towns in Australia.

\section{The Remote and Isolated Communities Essential Services Project}

There are an increasing number of water monitoring and conservation projects that have been developed and rolled out by service providers in remote Indigenous towns, ranging from small $(n<10)$ pilot studies to whole-of-community water use monitoring and water conservation programs (Yuen 2004, Beard et al 2013, Jenkins 2013, Ross et al. 2014). However, there is little detailed understanding of water and energy use trends in these communities at a disaggregated end-use resolution. Knowledge of the detailed water and energy end-use consumption patterns of residents, and understanding the drivers behind water use behaviours and attitudes, will improve the ability of planners, essential services staff, engineers, policy makers and community engagement officers to deliver suitable, efficient and fit-forpurpose water and wastewater infrastructure to those communities.

The Remote and Isolated Communities Essential Services (RICES) project is a three year research effort aimed at gathering baseline evidence and subsequently identifying sustainable strategies to reduce energy and water consumption in remote Aboriginal and Torres Strait Island communities. There are three broad objectives or stages of the RICES project i) identifying baseline water and energy use through the use of desktop modelling of existing datasets and installation of intelligent metering technology to gather high resolution end-use data ii) testing community-led water and energy efficiency strategies including technological and behavioural approaches and iii) developing a strategic framework/handbook to facilitate the successful adoption of identified appropriate efficiency education and retrofit strategies across northern Australian remote communities. Fig 1 is a broad representation of the methods for each stage of the project. Stage 1 of the research is currently underway where approximately 45 households in three remote Aboriginal and Torres Strait Island communities in Queensland and Northern Territory are being monitored for water (total and hot water) and energy (total and hot water system). Household water use surveys are also being conducted for all participating households to characterise the water and energy stock within each home and also to capture some behavioural and attitudinal data regarding household and community water and energy use. Concurrent to this, Stage 1 also involves desktop modelling using existing baseline water and energy data to provide some initial insights into the current water-energy demand, and potential range of reductions that may be achieved from implementing water efficient strategies. This paper reports on this desktop modelling component. 
Three case study communities have been selected for the desktop study. The first is located: in the Torres Strait Islands (i.e. Coral Sea), Queensland and shall be identified as "Site 1", the second is located in central Northern Territory ("Site 2") and the third is situated on Cape York, Far North Qld ("Site 3").

Site 1 has 315 residents who rely on their electricity supply via diesel generators and their potable water supply from a high energy intensity desalination plant Site 2 is a small community in Central Australia where around 530 residents rely on treated bore water. Unlike the other sites, their electricity supply is via a grid network, thus they are not reliant on diesel generators. Site 3 is a remote, off-grid coastal town in Cape York Peninsula of around 270 people who rely on diesel generated groundwater bores to supply water.

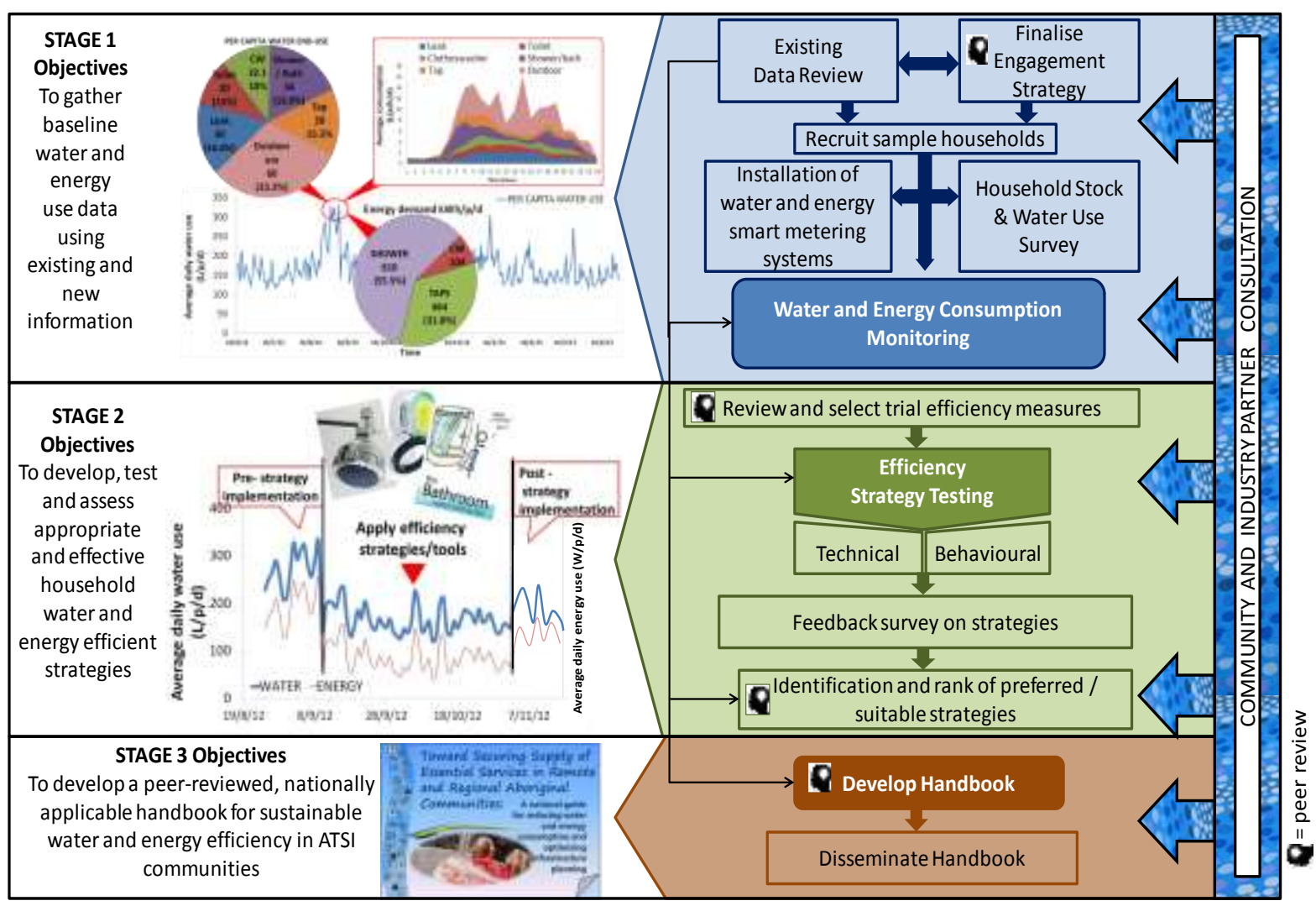

Fig. 1. Overview of objectives and methods for the RICES project

\section{Methods}

Modelling for this desktop study presented herein is based on comparing a before and after scenario where business as usual (BAU) water and energy demand from residential and non-residential activities is compared with post-retrofit water and water-related energy consumption. Retrofit refers to waterefficient technology replacing standard water using fixtures and appliances within the home. The method and assumptions used in the modelling are described below. 


\section{Water demand modelling}

\section{Separating the residential and non-residential component}

Available water consumption data for the three study areas was supplied by the service providers and was quite variable in terms of resolution, source and time period. The data consisted of average annual water consumption data for Site 1, monthly water consumption in Site 2 (from January 2014 to June 2015), and daily bore water extraction of Site 3 (from January 2015 to April 2016). The water consumption data for Site 2 and Site 3 are shown in Fig 2. The population profiles (i.e. total population and persons per household) for the study areas were obtained from the Australian Bureau of Statistics (ABS) and the Office of Economic and Statistical Research (OESR). This information was used to estimate average water demand for each study area on a litre per person per day $(\mathrm{L} / \mathrm{p} / \mathrm{d})$ basis.

For Sites 1 and 3, only total water consumption was available, the residential and non-residential demand (e.g. commercial demand, non-revenue water losses), components were firstly needed to be determined. This was able to be done using data for Site 2, where hourly residential water consumption data for 14 homes were available for the period May 2015 to July 2015. The average day demand for these 14 homes were extrapolated across the population and compared against recorded total water demand for the same period. The difference was taken to be the non-residential component and expressed as a percentage of the total average per person demand, resulting in a $66 \%$ and $34 \%$ split for the residential and non-residential components, respectively. These distributions were applied to Site 1 and Site 3 to separate the two demand components.

\section{Estimating individual end-use consumption}

The study used the method derived from a previous study (Gurung et al., 2014) which was based on smart water meter data from the South East Queensland Residential end use study (SEQREUS) (Beal and Stewart, 2011) to estimate the demand for the different water end-uses. The method firstly requires the indoor and outdoor demand to be separated using linear regression equations obtained for the two components in the SEQ region (Gurung et al., 2014). Indoor end-use demands were then estimated by applying the obtained indoor demand to individual indoor end-use distributions provided in Gurung et al. (2014). Measured differences in end-use consumption between efficient and non-efficient appliances, including shower, taps, toilets and clothes washers, were obtained from Gurung et al. (2015). These savings were then used to calculate water demand from each of the end-uses assuming a scenario where water-efficient technology has been retrofitted in each home for all three communities. A conservative estimate of a 50\% reduction in leakage was used based on Britton et al. (2013) and Ross et al (2014).

Beal et al. (2011) and Willis et al. (2013) discuss the impacts of water-efficient devices on total household water consumption (and water-related energy e.g. hot water reductions) and also on specific end-uses. For this modelling exercise, the BAU and post-retrofit for seven end uses were compared. 
Shower consumption efficiency was assumed to occur from the installation of low-flow showerheads that have shown to be significant in reducing cold and hot water use. Tap (bath and sink taps) end-uses can be reduced through the installation of flow restrictors and flow aerators. Clothes washing water demand can be reduced by using water-efficient, " 5 star" rated machines that are often front-loading and require one (cold) tap fitting only. Many toilets are now dual systems with full and half flush options, although survey results from recent field work for the RICES project suggest very few toilets in remote Indigenous communities are equipped with dual flush systems. Outdoor water use can be supplemented from rainwater tanks (see below) and also reduced through the use of trigger hoses and tap aerator devices. The reduction in leaks were based on households that have all these types of waterefficient devices and the related reduction in leaks that have been measured (Beal and Stewart 2011).

\section{Rainwater tank demand}

Although rainwater tanks are installed in some of the households in the study areas, many were found to be used either intermittently or not at all, particularly at Sites 2 and 3. Hence, this modelling also considers the effective utilisation of rainwater tanks in contributing to water savings. The urban water balance model UVQ (Mitchell and Diaper, 2010) was used to determine water savings for rainwater tanks for each community. Individual rainwater tanks in Site 3 were observed to be between $5 \mathrm{~kL}$ and $10 \mathrm{~kL}$; hence, a tank size of $7.5 \mathrm{~kL}$ was used in the model. The runoff coefficient was taken as 0.875 , and average roof areas for each study site was estimated using Google Earth ${ }^{\mathrm{TM}}$. Historic rainfall data were obtained from the Bureau of Meteorology (BOM) and the tanks were assumed to supply outdoor demand only.

\section{Energy savings}

\section{Energy intensity}

To estimate the costs savings of reduced energy consumption from reduced water consumption as a result of the retrofitting, the energy intensities $(\mathrm{kWh} / \mathrm{kL})$, which is the energy $(\mathrm{kWh})$ required in pumping or treating a unit $(\mathrm{kL})$ of water, of the water infrastructure in the three study areas were determined from available data.

The average energy intensity for the desalination and water treatment plant in Site 1 was estimated to be $5.4 \mathrm{kWh} / \mathrm{kL}$ based on an annual energy consumption of $27,000 \mathrm{kWh}$ and the community's water demand of $50,000 \mathrm{~kL}$. Of the total energy intensity, $5.0 \mathrm{kWh} / \mathrm{kL}$ was assumed for desalination purposes and $0.4 \mathrm{kWh} / \mathrm{kL}$ for pumping and treatment. An energy intensity of $0.15 \mathrm{kWh} / \mathrm{kL}$ was used for the treatment unit based on data from Site 2; this energy intensity was also used for the water treatment plant in Site 3, and the remaining $0.25 \mathrm{kWh} / \mathrm{kL}$ for pumping.

The energy intensity of the bore and transfer pumps, and the water treatment unit in Site 2 were estimated through available energy and water consumption data for the period of January 2014 to June 
2015. In Site 3, pump energy data was provided for March 2016 and April 2016 and used alongside bore water extraction for the same period to determine the energy intensity of the bore pumps. The recirculation pumps in Site 3 are variable speed pumps with a small pressure vessel, and any water use triggers the pumps according to demand required. As it is difficult to estimate pumping capacities of variable systems, due to the flow and energy variability, an average energy intensity of $3.02 \mathrm{kWh} / \mathrm{kL}$ was used from a study of a communal rainwater system (Cook et al., 2013) using a similar recirculation pumping system. The monthly water and energy consumption data for Site 2 and water demand for Site 3 are shown in Fig 2.

All homes in the study areas are assumed to have a solar water heater system with electricity booster (i.e. electricity as a backup system). An energy intensity of $10.8 \mathrm{kWh} / \mathrm{kL}$ was used based on a study on water heaters in Brisbane by Vieira et al. (2014).
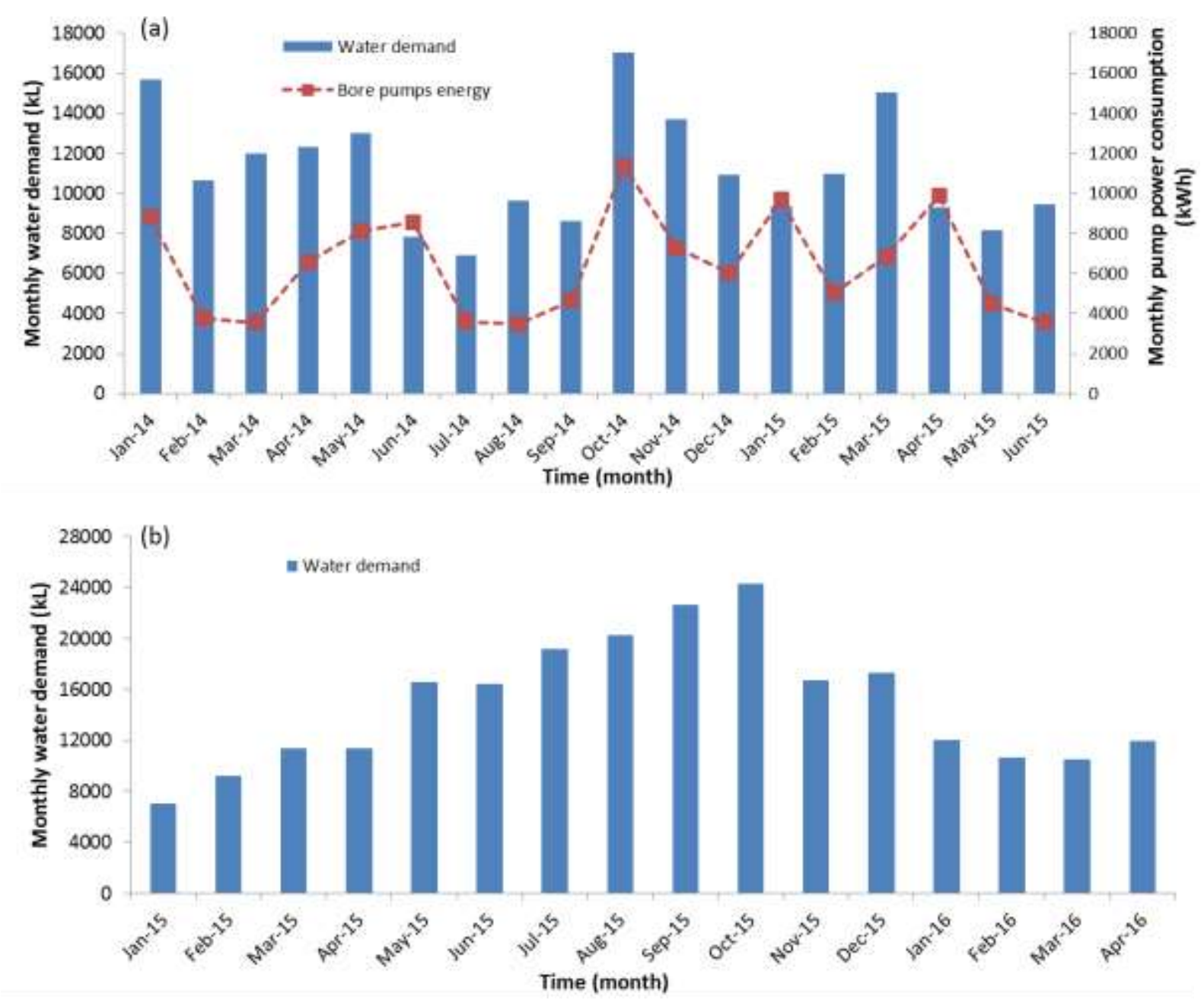

Fig 2 (a) Water demand, bore pump and treatment unit energy consumption in Site 2 (b) Bore water extraction in Site 3. 


\section{Energy costs}

A one year average (May 2015 to May 2016) Australian wholesale diesel price (including taxes) of $\$ 1.09$ per litre, obtained from the Australian Institute of Petroleum (AIP), was used to estimate the cost savings in running the diesel generators for Site 1 and Site 3 following reduced demand from retrofitting water-efficient technology. Power and Water Corporation, the energy provider for the Northern Territory site, estimates the cost of providing electricity in Site 2 to be $\$ 0.2554$ per $\mathrm{kWh}$.

\section{Modelling parameters}

A summary of final modelling parameters used to undertake the analysis are shown in Table 1.

Table 1 Summary of modelling input parameters and assumptions

\begin{tabular}{|c|c|c|c|c|c|}
\hline Input parameter & Site 1 & Site 2 & Site 3 & Unit & Comments / sources \\
\hline \multicolumn{6}{|l|}{ Population profile } \\
\hline Population & 315 & 535 & 270 & persons & \\
\hline Average household size & 3.6 & 4.8 & 3.3 & $\begin{array}{l}\text { persons/ } \\
\text { home }\end{array}$ & $\begin{array}{l}\text { Site } 1 \text { (ABS, 2011a), Site } 2 \text { (ABS, } \\
\text { 2011b), Site } 3 \text { (OESR, 2012) }\end{array}$ \\
\hline \multicolumn{6}{|l|}{ Water consumption } \\
\hline Total water consumption & 435 & 687 & 1,835 & $\mathrm{~L} / \mathrm{p} / \mathrm{d}$ & Water consumption data \\
\hline - Residential & 287 & 453 & 1,211 & $\mathrm{~L} / \mathrm{p} / \mathrm{d}$ & $66 \%$ of total consumption \\
\hline - Non- residential & 148 & 234 & 624 & $\mathrm{~L} / \mathrm{p} / \mathrm{d}$ & $34 \%$ of total consumption \\
\hline \multicolumn{6}{|l|}{ Rainwater tank modelling } \\
\hline Roof area & 290 & 220 & 220 & $\mathrm{~m}^{2}$ & Google Earth ${ }^{\mathrm{TM}}$ \\
\hline Amount of rainfall data & 13 & 20 & 20 & $\begin{array}{l}\text { Years } \\
\text { (y) }\end{array}$ & $\begin{array}{l}\text { Bureau of Meteorology Climate Data } \\
\text { online stations 027045, 027054, } \\
015608 \text { ) }\end{array}$ \\
\hline \multicolumn{6}{|l|}{ Energy intensity } \\
\hline Desalination plant & 5.00 & N/A & N/A & $\mathrm{kWh} / \mathrm{kL}$ & $\begin{array}{l}\sim 270,000 \mathrm{kWh} \text { to treat } \sim 50,000 \mathrm{~kL} \\
\text { per annum. Data provided by service } \\
\text { provider. }\end{array}$ \\
\hline Bore pumps & N/A & 0.58 & 0.36 & $\mathrm{kWh} / \mathrm{kL}$ & $\begin{array}{l}\text { Water and energy consumption data } \\
\text { provided by service provider. }\end{array}$ \\
\hline Transfer/ recirculation pumps & 0.25 & 0.15 & 3.02 & $\mathrm{kWh} / \mathrm{kL}$ & $\begin{array}{l}\text { Water and energy consumption data } \\
\text { provided by service provider. }\end{array}$ \\
\hline Water treatment plant & 0.15 & 0.15 & 0.15 & $\mathrm{kWh} / \mathrm{kL}$ & Estimated from Site 2 data \\
\hline Solar water heaters & 10.8 & 10.8 & 10.8 & $\mathrm{kWh} / \mathrm{kL}$ & Vieira et al. (2014) \\
\hline \multicolumn{6}{|l|}{ Cost parameters } \\
\hline Cost of diesel per litre & \multicolumn{3}{|l|}{1.09} & $\$ / L$ & AIP (2016) \\
\hline Diesel for powering generators & \multicolumn{3}{|l|}{0.30} & $\mathrm{~L} / \mathrm{kWh}$ & Ergon Energy \\
\hline
\end{tabular}




\begin{tabular}{|l|l|l|l|l|l|}
\hline $\begin{array}{l}\text { Cost of diesel for powering } \\
\text { desalination/ bore pump }\end{array}$ & 0.327 & N/A & 0.327 & $\$ / \mathrm{kWh}$ & AIP (2016) \\
\hline $\begin{array}{l}\text { Cost of supplying from power } \\
\text { grid }\end{array}$ & N/A & 0.2554 & N/A & $\$ / \mathrm{kWh}$ & Power and Water Corporation \\
\hline
\end{tabular}

\section{Results and discussion}

\section{Water demand modelling}

The business as usual (BAU) residential water consumption for the three study areas were $287 \mathrm{~L} / \mathrm{p} / \mathrm{d}$, $453 \mathrm{~L} / \mathrm{p} / \mathrm{d}$ and 1,211 L/p/d for Site 1, Site 2 and Site 3, respectively. Water consumption for all study areas were disaggregated into individual end-uses and the assumed reduced consumption from the water efficient appliance retrofit scenario was applied to determine the water savings for indoor appliances. Outdoor water savings from utilising rainwater tanks were determined through the use of the water balance model, UVQ, and were calculated to be $58 \%, 17 \%$ and $31 \%$ for Site 1, Site 2 and Site 3, respectively.

The results of the water demand modelling indicate that the use of water efficient appliances and rainwater tanks have the potential to reduce total water consumption in the three areas by $43 \%$ for Site 1,28\% for Site 2 and 33\% for Site 3. The modelled water demand for individual end-uses for the BAU and retrofit scenarios are presented in Table 2.

Table 2 Modelled end use demands for BAU and retrofit scenarios in the three study areas

\begin{tabular}{|l|l|l|l|l|l|l|l|l|}
\hline & \multicolumn{3}{|l|}{ BAU (L/p/d) } & \multicolumn{2}{l|}{ Retrofit (L/p/d) } & \multicolumn{2}{l|}{ Site 3 } \\
& $\begin{array}{l}\text { Indoor } \\
\text { use (\%) }\end{array}$ & Site 1 & Site 2 & Site 3 & $\begin{array}{l}\text { Assumed } \\
\text { Savings } \\
(\%)\end{array}$ & Site 1 & Site 2 & Site \\
\hline Shower & 35 & 67.5 & 93.1 & 209.7 & 40 & 40.5 & 55.8 & 125.8 \\
\hline Tap & 16 & 30.8 & 42.5 & 95.9 & 20 & 24.7 & 34.0 & 76.7 \\
\hline Bath & 2 & 3.9 & 5.3 & 12.0 & 0 & 3.9 & 5.3 & 12.0 \\
\hline Toilet & 19 & 36.6 & 50.5 & 113.9 & 20 & 29.3 & 40.4 & 91.1 \\
\hline Clothes washer & 23 & 44.3 & 61.2 & 137.8 & 50 & 22.2 & 30.6 & 68.9 \\
\hline Leakage & 5 & 9.6 & 13.3 & 30.0 & 50 & 4.8 & 6.6 & 15.0 \\
\hline Outdoor & N/A* & 94.4 & 187.5 & 611.9 & $17-58^{* *}$ & 39.6 & 155.6 & 422.2 \\
& & & & & & $(58 \%)$ & $(17 \%)$ & $(31 \%)$ \\
\hline Total & N/A & 287.1 & 453.4 & 1211.1 & N/A & 164.9 & 328.5 & 811.7 \\
\hline
\end{tabular}

*Outdoor demand obtained from indoor-outdoor demand split. **Calculated outdoor water savings from rainwater tanks are in parentheses for each study area.

Hot water demand was estimated as a percentage of the obtained indoor individual end-use consumption; 25\% for clothes washer (EBMUD, 2008) and 50\% for showers, taps and bath (Kenway 
et al., 2008). In all areas, hot water demand reduced by $36 \%$ of the original hot water demand; potentially representing significant energy savings. Table 3 shows the BAU and retrofitted hot water demand for the individual appliances.

Table 3 Modelled hot water demand of each end-use for BAU and retrofit scenarios

\begin{tabular}{|l|l|l|l|l|l|l|l|}
\hline & \multicolumn{3}{|l|}{ BAU (L/p/d) } & \multicolumn{3}{l|}{ Retrofit (L/p/d) } \\
\hline & $\begin{array}{l}\text { Hot water } \\
\text { proportion (\%) }\end{array}$ & Site 1 & Site 2 & Site 3 & Site 1 & Site 2 & Site 3 \\
\hline Shower & 50 & 33.7 & 46.5 & 104.9 & 20.2 & 27.9 & 62.9 \\
\hline Tap & 50 & 15.4 & 21.3 & 47.9 & 12.3 & 17.0 & 38.4 \\
\hline Bath & 50 & 1.9 & 2.7 & 6.0 & 1.9 & 2.7 & 6.0 \\
\hline Clothes washer & 25 & 0.0 & 0.0 & 0.0 & 0.0 & 0.0 & 0.0 \\
\hline Total & - & 0.0 & 0.0 & 0.0 & 0.0 & 0.0 & 0.0 \\
\hline
\end{tabular}

+ Hot water proportion is represented as a percentage of the modelled demand for each end-use

\section{Water and energy savings}

The results from the modelling show that retrofitting toilets, taps, clothes washers and shower heads with efficient appliances in the community and the efficient use of rainwater tanks for outdoor use is expected to reduce residential consumption by $43 \%, 28 \%$ and $33 \%$ in Site 1, Site 2 and Site 3, respectively. This represents a corresponding annual water reduction of $14 \mathrm{ML}, 24 \mathrm{ML}$ and $39 \mathrm{ML}$, respectively for Sites 1, 2 and 3. There is potential for further water savings to be achieved as the modelling does not take into account the potential for using water efficient technology in non-residential areas. Table 4 presents the overall annual water and energy savings from the retrofitting project.

The reductions in water demand are expected to result in lower energy consumption in all three study areas due to reduced desalination, treatment and pumping demand, as well as a decrease in the energy required for heating water (i.e. reduced hot water use meant less diesel generated energy needed for electric heating systems). Diesel savings of 31,000 kL and 63,640 kL per year are expected in Site 1 and Site 3, respectively, while Site 2, which is supplied through a normal electricity grid, is expected to save $87,700 \mathrm{kWh}$.

The energy intensities for the pumps transferring/reticulating treated water at Site 1 and Site 2 are considerably lower than for Site 3 (Column E in Table 4). This is due to that fact that at these sites, treated water is transferred to an elevated tank, compared with Site 3 where the pressurised recirculation pumps are used to distributed the treated water, up to $5 \mathrm{~km}$ away, thus the opportunity for savings gained from reduced demand will be greater at Site 3. 
Table 4 Estimated annual savings in water, energy and cost from the retrofitting project

\begin{tabular}{|c|c|c|c|c|c|}
\hline Item & Description & & & & Unit $^{\#}$ \\
\hline \multirow[t]{3}{*}{ A } & Water savings - total demand & Site 1 & Site 2 & Site 3 & \\
\hline & Annual BAU water demand & 50,014 & 134,154 & 180,839 & $\mathrm{~kL} / \mathrm{a}$ \\
\hline & Post retrofit demand & 35,966 & 109,756 & 141,477 & $\mathrm{~kL} / \mathrm{a}$ \\
\hline $\mathbf{B}$ & Total water savings from retrofit ( $100 \%$ diffusion) & 14,048 & 24,398 & 39,362 & $\mathbf{k L} / \mathbf{y}$ \\
\hline \multirow[t]{5}{*}{$\mathrm{C}$} & Water related savings in energy (diesel and power grid) & & & & \\
\hline & BAU energy required for desal. plant/ bore pumps & 250,071 & 77,809 & 65,102 & $\mathrm{kWh} / \mathrm{y}$ \\
\hline & Post retrofit energy required for desal. plant/ bore pumps & 179,829 & 63,658 & 50,932 & $\mathrm{kWh} / \mathrm{y}$ \\
\hline & Savings in energy for desal. plant/ bore pumps & 70,242 & 14,151 & 14,170 & $\mathrm{kWh} / \mathrm{y}$ \\
\hline & Cost savings for energy & 22,969 & 3,614 & 4,634 & $\$ / y$ \\
\hline \multirow[t]{5}{*}{$\mathrm{D}$} & Savings in water treatment (diesel and power grid) & & & & \\
\hline & BAU estimated energy demand for treatment & 7,502 & 20,123 & 27,126 & $\mathrm{kWh} / \mathrm{y}$ \\
\hline & Post retrofit energy required for treatment & 5,395 & 16,463 & 21,222 & $\mathrm{kWh} / \mathrm{y}$ \\
\hline & Savings in energy for treatment & 2,107 & 3,660 & 5,904 & $\mathrm{kWh} / \mathrm{y}$ \\
\hline & Cost savings for energy & 689 & 935 & 1,931 & $\$ / y$ \\
\hline \multirow[t]{5}{*}{$\mathrm{E}$} & $\begin{array}{l}\text { Savings in transfer/ recirculation pumps energy (diesel and } \\
\text { power grid) }\end{array}$ & & & & \\
\hline & BAU pumping energy required for transfer/ recirc. pumps & 12,504 & 20,123 & 546,135 & $\mathrm{kWh} / \mathrm{y}$ \\
\hline & Post retrofit energy required for transfer/ recirc. pumps & 8,991 & 16,463 & 427,262 & $\mathrm{kWh} / \mathrm{y}$ \\
\hline & Savings in energy for transfer/ recirc. pumps & 3,512 & 3,660 & 118,873 & $\mathrm{kWh} / \mathrm{y}$ \\
\hline & Cost savings for energy & 1,148 & 935 & 38,871 & $\$ / y$ \\
\hline \multirow[t]{6}{*}{$\mathrm{F}$} & Hot water savings in energy (diesel and power grid) & & & & \\
\hline & Annual BAU hot water demand & 7,147 & 16,745 & 19,045 & $\mathrm{~kL} / \mathrm{y}$ \\
\hline & Annual post retrofit hot water demand & 4,604 & 10,787 & 12,269 & $\mathrm{~kL} / \mathrm{y}$ \\
\hline & Reduction in hot water demand & 2,543 & 5,958 & 6,777 & $\mathrm{~kL} / \mathrm{y}$ \\
\hline & Savings in energy for reduced hot water required & 27,464 & 64,348 & 73,187 & $\mathrm{kWh} / \mathrm{y}$ \\
\hline & Cost savings for energy & 8,981 & 16,434 & 23,932 & $\$ / y$ \\
\hline $\mathbf{G}$ & Total energy savings from retrofit (100\% diffusion) & 98,746 & 83,094 & 208,161 & \\
\hline \multirow[t]{3}{*}{$\mathrm{H}$} & Total energy costs & & & & \\
\hline & BAU costs & 113,672 & 74,936 & 225,158 & $\$ / y$ \\
\hline & Retrofitted costs & 80,257 & 53,737 & 167,202 & $\$ / y$ \\
\hline \multirow[t]{4}{*}{ I } & Total monetary savings & & & & \\
\hline & $100 \%$ diffusion of retrofit programme to population & 33,787 & 21,918 & 69,368 & $\$ / y$ \\
\hline & $75 \%$ diffusion of retrofit programme to population & 25,341 & 16,439 & 52,026 & $\$ / y$ \\
\hline & $50 \%$ diffusion of retrofit programme to population & 16,894 & 10,959 & 34,684 & $\$ / y$ \\
\hline
\end{tabular}

\# Units: kL/a - kilolitre per annum; kWh/a - kilowatt hour per annum; \$/a - Australian dollars (AUD) per annum 
A reduction of around $36 \%$ for residential post-retrofit hot water use represents a substantial portion of the water and water-related energy demand per household compared to BAU (Table 3). The main driver for this reduction is the lower shower hot water use resulting from the retrofitting of low flow showerheads. This end-use comprises the highest proportion of indoor use (35\%) with half of its total volume being supplied by hot water. Others have also reported that replacing standard shower heads with water efficient shower heads (e.g. $9 \mathrm{~L} /$ minute) can reduce both hot and cold water consumption significantly (Beal et al., 2012; Vieira et al., 2014).

Monetary savings have been estimated from this program which range from AUD \$11,000 per year (50\% diffusion of the program on residential properties) to around $\$ 69,400$ per annum (100\% diffusion). A halfway point for this is the $75 \%$ diffusion which is the most likely scenario given the small population of the three study areas and relative ease of widespread social diffusion of the program. This would amount to around annual savings of $\$ 25,300, \$ 16,400$ and $\$ 52,000$ for Site 1, Site 2 and Site 3, respectively, which would represent a savings of approximately $22 \%$ of original BAU costs. This also does not consider the reduction in community service obligation payments that the Queensland Government are required to subsidise energy utilities in non-urban regions.

Further energy savings will also be possible through integrating more capital intensive supply side solutions such as a renewable energy system (wind and solar farm) on the island with an energy storage bank. To highlight this, an analysis was conducted considering the installation of solar bore pumps in the two sites using bore-water; one pump in Site 2 and two pumps in Site 3. These solar bore pumps were assumed to have similar specifications to currently operational bore pumps in these two sites. The average daily peak sun hours were estimated from 20-year solar data obtained from the BOM and were 6.2 hours and 5.7 hours for Site 2 and Site 3, respectively. The peak sun hours were used to calculate the total demand the bore pumps are able to pump when operating at full capacities, with the remaining demand pumped by the existing bore pumps. Table 5 presents the annual energy and cost savings from installing solar bore pumps.

Table 5 Annual energy and cost savings from installing solar bore pumps

\begin{tabular}{|l|l|l|l|l|l|l|l|l|l|}
\hline & & \multicolumn{4}{|c|}{ Site 2 } & \multicolumn{4}{|c|}{ Site 3 } \\
\hline \multirow{3}{*}{ Scenario } & $\begin{array}{l}\text { Uptake } \\
\text { of } \\
\text { retrofit } \\
\text { program }\end{array}$ & $\begin{array}{l}\text { Water } \\
\text { demand } \\
(\mathrm{kL})\end{array}$ & $\begin{array}{l}\text { Pumping } \\
\text { energy } \\
\text { required } \\
(\mathrm{kWh})\end{array}$ & $\begin{array}{l}\text { Energy } \\
\text { costs } \\
(\$)\end{array}$ & $\begin{array}{l}\text { Cost } \\
\text { savings } \\
(\$)\end{array}$ & $\begin{array}{l}\text { Water } \\
\text { demand } \\
(\mathrm{kL})\end{array}$ & $\begin{array}{l}\text { Pumping } \\
\text { energy } \\
\text { required } \\
(\mathrm{kWh})\end{array}$ & $\begin{array}{l}\text { Energy } \\
\text { costs } \\
(\$)\end{array}$ & $\begin{array}{l}\text { Cost } \\
\text { savings } \\
(\$)\end{array}$ \\
\hline BAU & - & 134,154 & 77,809 & 19,872 & - & 180,839 & 65,102 & 21,288 & - \\
\hline $\begin{array}{l}\text { Solar } \\
\text { pumps } \\
\text { installed }\end{array}$ & $100 \%$ & 109,756 & 35,307 & 9,018 & 10,855 & 141,477 & 33,855 & 11,071 & 10,218 \\
\cline { 2 - 11 } & $75 \%$ & 115,855 & 38,845 & 9,921 & 9,951 & 151,318 & 37,398 & 12,229 & 9,059 \\
\hline
\end{tabular}


The results of the analysis indicate that there are considerable savings. Assuming a scenario of $75 \%$ diffusion of retrofit technology and the installation of solar-powered bore pumps, an annual cost savings of $\$ 9,921$ and $\$ 9,059$ are estimated for Site 2 and Site 3, respectively, representing almost $50 \%$ of original pumping energy costs. Although the capital and operating costs of the solar pumps have not been taken into consideration, the pump energy savings, along with the original costs savings from the retrofitting scheme, are expected to offset these costs.

Energy prices continue to rise globally and there is potential for the water-related energy savings from the efficiency project to increase over the long term. Hall (2013) predicted electricity prices to 'most likely' rise by $5 \%$ in the future, while oil prices are more erratic and difficult to predict and are influenced by global demand. Hence, based on a 5\% annual increase in the cost of electricity and diesel fuel, the estimated 10 year savings are approximately $\$ 360,000, \$ 234,000$ and $\$ 739,000$ for Site 1 , Site 2 and Site 3, respectively, assuming a 75\% uptake of the retrofit efficiency scheme. With the use of solar bore pumps, the latter two savings correspondingly increase to approximately $\$ 375,000$ and $\$ 848,000$. These savings do not take into account the cost of retrofitting the appliances or the cost of the bore pumps. However, the substantial costs savings provide evidence that the implementation of the retrofitting project has the potential to offset any additional costs which the scheme may incur. This is outside the scope of this modelling study and additional research is required on the potential net positive benefits for retrofitting appliances in remote communities.

Along with the cost and energy savings produced from this study, there are several other direct and indirect benefits and savings to be realised from introducing a water-efficient technology retrofit program. These include:

- reduced transport of diesel to remote islands and communities;

- reduced greenhouse gas emissions for diesel fuel us;

- instilling ongoing water and energy conservation practices amongst residents;

- desalination plant operation and maintenance cost reduction;

- power plant operation and maintenance cost reduction; and

- more accurate consideration of the capital and life cycle cost benefits of plant life spans.

\section{Modelling assumptions and limitations}

There are a number of assumptions and limitations associated with any modelling approach. For this study, the known average total per capita water use on the three sites was disaggregated into seven enduses based on the SEQREUS - an urban residential end-use study that comprised a very minimal representation of Aboriginal and Torres Strait Islander people. The modelling also assumes that the savings that were achieved from water efficient technologies and behaviours in south east Queensland (urban residential) will be directly transferable to regional Indigenous communities. Obviously, this is 
unlikely to be the case, particularly for any associated behavioural changes where cultural practices, social norms and attitudes to water use may be quite different (Jackson, 2006). To attempt to dampen the error relating to this, the modelling only assumes the savings based on the introduction of water efficient technologies (e.g. low flow shower heads, tap restrictors and water efficient clothes washers), rather than also assuming ongoing reductions to water consumption. It is acknowledged that there will still be differences in use of the fixtures and appliances by both groups (urban vs isolated), however once empirical data has been obtained from Stage 2 of the RICES project, the predicted savings will be compared to the observed savings in order to verify the model and the effectiveness of the strategies. The model also assumes that there is no existing penetration of the water efficient technologies within the community to start with. Although not exhaustive, 30 household water use surveys conducted in Site 2 and Site 3 did indicate that there is very limited penetration of water-efficient devices (e.g. no indication of low-flow shower heads, outdoor trigger hoses, and tap aerators and restrictors were observed during the household water use surveys).

Furthermore, it is acknowledged that there are some underlying assumptions of transferability between the communities in terms of the proportion of non-residential and residential properties, however there are strong similarities between the sizes of the communities and the number and type of non-residential premises (e.g. all have council offices, schools, health centres, shops and community buildings). What is less certain are the behavioural aspects of water use for residential and non-residential activities and whether these are transferable across the communities. Stage 2 of the RICES project will identify and clarify many of these assumptions and incorporate them into the final modelling phase of this work.

\section{Conclusions}

This paper presents modelling results from a scenario where water efficient strategies were retrofitted in three remote communities in Far North Queensland and central Northern Territory. The modelling demonstrated appreciable savings to both the water and energy average daily consumption through demand reduction on the energy intensive desalination plants or water pumping infrastructure. It has been estimated that such a retrofit program could potentially save between $\$ 16,400$ and $\$ 52,000$ (Australian Dollars) per year in saved energy costs, assuming $75 \%$ of the population implement the water efficiency retrofit program. Based on a 5\% annual increase in the cost of diesel, the estimated 10 year savings achievable is between $\$ 234,000$ and $\$ 739,000$. Further savings were realised by substituting diesel-run bore pumps with solar powered pumps for the two sites that rely on bore water. This desktop case study represents the initial stages of a larger project examining the management of essential water and energy services in remote and isolated communities. The overall outcome of the project is to ensure that such strategies are practical to implement on a broader scale to ultimately achieve more sustainable water and energy efficient off-grid communities.

\section{Acknowledgements}


The funding for the RICES project is through an Australian Research Council Linkage Grant and a Queensland State Government Accelerate Fellowship. The authors would also like to acknowledge the project industry partners for their cash and/or in-kind contributions: Ergon Energy (Qld), Power and Water (NT), Centre for Appropriate Technology, Department of Energy and Water Supply, Torres Strait Island Regional Council, Western Australian Water Corporation and the University of Queensland.

\section{References}

ABS (Australian Bureau of Statistics), (2011a). 2011 Census QuickStats, http://www.censusdata.abs.gov.au/census services/getproduct/census/2011/quickstat/UCL32205 $\underline{6}$ ?opendocument\&navpos $=220$ (accessed May 2016).

ABS (Australian Bureau of Statistics), (2011b). 2011 Census QuickStats, http://www.censusdata.abs.gov.au/census_services/getproduct/census/2011/quickstat/UCL72100 $\underline{1}$ ?opendocument\&navpos $=220$ (accessed May 2016).

AIP (Australian Institute of Petroleum), (2016). Terminal gate prices. Available at: http://www.aip.com.au/pricing/tgp/index.htm (accessed May 2016).

Beal, C. D., Bertone, E., Stewart, R. A. (2012). Evaluating the energy and carbon reductions resulting from resource-efficient household stock. Energy and Buildings, 55, 422-432,

Beal, C., Larsen, S. \& Stewart, R. (2014) Exploring the residential water-energy nexus in remote regions: results from a Far North Queensland water end-use pilot study. Australian Water Association Journal 41, 78-82

Beard, N., Climie, K., Vervetjes, E., Saunders, P. and Gerard, W. (2013) Business case and implementation of efficiency - NT Indigenous Communities, Ozwater 13 Conference Proceedings, Perth, 7-9 May.

Britton, T.C., Stewart, R.A. and O'Halloran, K.R. (2013) Smart metering: enabler for rapid and effective post meter leakage identification and water loss management. Journal of Cleaner Production 54(0), $166-176$.

Burgess, C., Johnston, F., Bowman, D. \& Whitehead, P. (2005) Healthy country: healthy people? Exploring the health benefits of Indigenous natural resource management Australian and New Zealand Journal of Public Health 29, 117-122

CAT Projects. (2012) Torres Strait - Options to Reduce Regional Carbon Footprint. (Ekistica Pty Ltd, trading as CAT Projects ABN 74126787853

Cook, S., Sharma, A., Chong, M. (2013). Performance Analysis of a communal residential rainwater system for potable supply: A case study in Brisbane, Australia. Water Resources Management, 27, 4865-4876.

EBMUD (East Bay Municipal Utility District). (2008). Water Smart Guide Book: a Water-use Efficiency Plan Review Guide for New Businesses. Oakland, California.

Fisher, S. et al. (2011) Desert Services that Work: Demand-responsive approaches to desert settlements. ( DKCRC Research Report 70. Ninti One Limited, Alice Springs, 2011). 
Gurung, T. R., Stewart, R. A., Sharma, A. K., Beal, C. D. (2014). Smart meters for enhanced water supply network modelling and infrastructure planning. Resources, Conservation and Recycling, 90, 34-50.

Gurung, T. R., Stewart, R. A., Beal, C. D., Sharma, A. K. (2015). Smart meter enabled water end-use demand data: platform for the enhanced infrastructure planning of contemporary urban water supply networks. Journal of Cleaner Production, 87, 642-654.

Grey-Gardner, R. (2008) Remote community water management. (Alice Springs, N.T. : Desert Knowledge Cooperative Research Centre.

Hoverman, S. \& Ayre, M. (2012) Methods and approaches to support Indigenous water planning: An example from the Tiwi Islands, Northern Territory, Australia. Journal of Hydrology 474, 47-56, doi:http://dx.doi.org/10.1016/j.jhydrol.2012.03.005

Hunter, E. (2007) Disadvantage and discontent: A review of issues relevant to the mental health of rural and remote Indigenous Australians. Aust. J. Rural Health 15, 88-93

Jackson, S. (2006) Compartmentalising Culture: the articulation and consideration of Indigenous values in water resource management. Aust. Geogr. 37, 19-31

Jenkins, M. (2013) Alternative approaches to remote indigenous community water management planning. (Ozwater 2013 Conference Proceedings, Perth, 7-9 May

Kaygusuz, K. (2011) Energy services and energy poverty for sustainable rural development. Renewable and Sustainable Energy Reviews 15, 936-947

Kenway, S. J., Priestley, A., Cook, C., Seo, S., Inman, M., Gregory, A., Hall, M. (2008). Energy use in the provision and consumption of urban water in Australia and New Zealand. CSIRO: Water for a Healthy Country National Research Flagship.

Mitchell, V.G. and Diaper, C. (2010) UVQ User Manual: (Urban Water Balance and Contaminant Balance Analysis Tool), Version 1.2CMIT Report No. 2005-282. CSIRO.

Mohtar, R.H. and Lawford, R. (2016) Present and future of the water-energy-food nexus and the role of the community of practice. Journal of Environmental Studies and Sciences 6(1), 192-199.

Moran, M. et al. (2007) The Transformation of Assets for Sustainable Livelihoods in a Remote Aboriginal Settlement. (DKCRC Research Report 28, Desert Knowledge CRC, Alice Springs 2007

Moran, M. \& Corpus, G. (2013) Adapting development practice to indigenous contexts. Development Bulletin 76, 79-83

OESR (Office of Economic and Statistical Research), (2012). Population and dwelling profile, Queensland Treasury and Trade, April 2012. Available at: http://www.qgso.qld.gov.au/products/reports/pop-housing-profiles-lga/pop-housing-profile (accessed May 2016).

O'Rourke, T. (2011) Delivering drinking water to Dajarra, North West Queensland. (DKCRC Report 64. Ninti One Limited, Alice Springs, Northern Territory

Richards, B. S. \& Schäfer, A. I. (2013) Photovoltaic-powered desalination system for remote Australian communities. Renewable Energy 28, 2013-2022 
Ross, K., Delaney, C., Beard, N., Fuller, K., Mohr, S. and Mitchell, C. (2014) Smart metering enables effective demand management design. Water: Journal of the Australian Water Association 41(5), 81.

Shezan, S.A., Saidur, R., Ullah, K.R., Hossain, A., Chong, W.T. and Julai, S. (2015) Feasibility analysis of a hybrid off-grid wind-DG-battery energy system for the eco-tourism remote areas. Clean Technologies and Environmental Policy 17(8), 2417-2430.

Vieira, A. S., Beal, C. D. \& Stewart, R. A. (2014) Residential water heaters in Brisbane, Australia: Thinking beyond technology selection to enhance energy efficiency and level of service. Energy Build. 82, 222-236

Werner, M. \& Schäfer, A. I. (2007) Social aspects of a solar-powered desalination unit for remote Australian communities. Desalination 203, 375-393

Willis, E., Pearce, M., McCarthy, C., Ryan, F. \& Wadham, B. (2008) Indigenous Responses to Water Policymaking in Australia. Society for International Development 51, 418-424

Yuen, E. (2005) Water consumption patterns in Australian Aboriginal communities, PhD Thesis, Remote Area Developments Group, Murdoch University, Western Australia, 321 pp. 